\title{
Recovery of Native Species following Rat Eradication on Mokoli'i Island, $\mathrm{O}^{`}$ ahu, Hawai ${ }^{\prime}{ }^{1}$
}

\author{
David G. Smith, ${ }^{2}$ Ethan K. Shiinoki, ${ }^{2,4}$ and Eric A. VanderWerf ${ }^{3}$
}

\begin{abstract}
Rats were eradicated from Mokolici, a 1.6-ha island off the east shore of $\mathrm{O}^{\prime}$ ahu, using snap traps, cage traps, and diphacinone bait stations. A total of 18 black rats (Rattus rattus) were caught, and 354 bait blocks were used. There was no sign of rats on the island after 27 May 2002. Wedge-tailed Shearwaters (Puffinus pacificus) nest on Mokoli'i, but only a single chick survived during 1999-2001; the number of surviving chicks increased to 126 in 2002 and 185 in 2003. The number of intertidal invertebrates and native plants, including the endangered Carter's panic grass (Panicum fauriei var. carteri), also appeared to increase after rat eradication. Rats had a devastating impact on the flora and fauna of Mokoli i $i$, and their eradication has allowed a dramatic recovery of native species. The majority of the labor for the eradication effort was provided by the local community, demonstrating what can be achieved with dedicated volunteers and community support.
\end{abstract}

Mокоli'i Island, also known as Chinaman's Hat due to its shape, is situated on the edge of Kāne'ohe Bay about $500 \mathrm{~m}$ east of Kualoa Point on the eastern shore of $\mathrm{O}^{\prime} \mathrm{ahu}$, Hawai' $i$, at latitude $21.31^{\circ} \mathrm{N}$, longtitude $157.50^{\circ} \mathrm{W}$ (Figure 1). The island has an area of $1.6 \mathrm{ha}$, is $63 \mathrm{~m}$ at its highest point, and is a geological example of a seastack. Mokoli'i is subject to prevailing northeasterly trade winds, experiences annual variation in average temperature from 20 to $28{ }^{\circ} \mathrm{C}$, receives an average annual rainfall of $120 \mathrm{~cm}$, and regular salt spray from the prevailing trade winds.

Mokoli' $\mathrm{i}$ is heavily vegetated, dominated by nonnative plant species such as Christmas

\footnotetext{
${ }^{1}$ Manuscript accepted 9 June 2005.

2 Department of Land and Natural Resources, Division of Forestry and Wildlife, 2135 Makiki Heights Drive, Honolulu, Hawai'i 96822.

${ }^{3}$ U.S. Fish and Wildlife Service, 300 Ala Moana Boulevard, Room 3-122, Box 50088, Honolulu, Hawai'i 96850 . com).

${ }^{4}$ Corresponding author (e-mail: eshiinoki@hawaii.rr.
}

Pacific Science (2006), vol. 60, no. 2:299-303

(C) 2006 by University of Hawai'i Press

All rights reserved berry (Schinus terebinthifolius) and lantana (Lantana camara), but it also harbors several native plant species including 'ilima (Sida fallax), naupaka kahakai (Scaevola sericea), pili grass (Heteropogon contortus), $\mathrm{pā}^{6} \mathrm{u} o h i$ 'iaka (Jacquemontia ovalifolia), and the endangered endemic Carter's panic grass (Panicum fauriei var. carteri) (Wagner et al. 1999). Mokoli'i is also a nesting site for the Wedge-tailed Shearwater (Puffinus pacificus), but nesting success on the island has been very low in recent years. Mokoli'i receives daily human recreational traffic, being adjacent to Kualoa Regional Beach Park. Foot traffic is largely restricted to existing perimeter and summit trails by thick vegetation and thorny lantana.

Black rats (Rattus rattus) have been present on Mokoli'i since the 1950s (C. Reppun, pers. comm., 2002) and are known to be a major predator of island birds, particularly groundand burrow-nesting seabirds (Atkinson 1977, 1985, Moors et al. 1992, McLennan et al. 1996, Zino et al. 2001), as well as plants, insects, intertidal mollusks, and other invertebrates (Tomich 1986). Because of these wide-ranging effects, the goal of this project was to eradicate black rats from Mokoli'i Island and to document any regeneration or recovery of seabird populations, native plants, and intertidal invertebrates. 


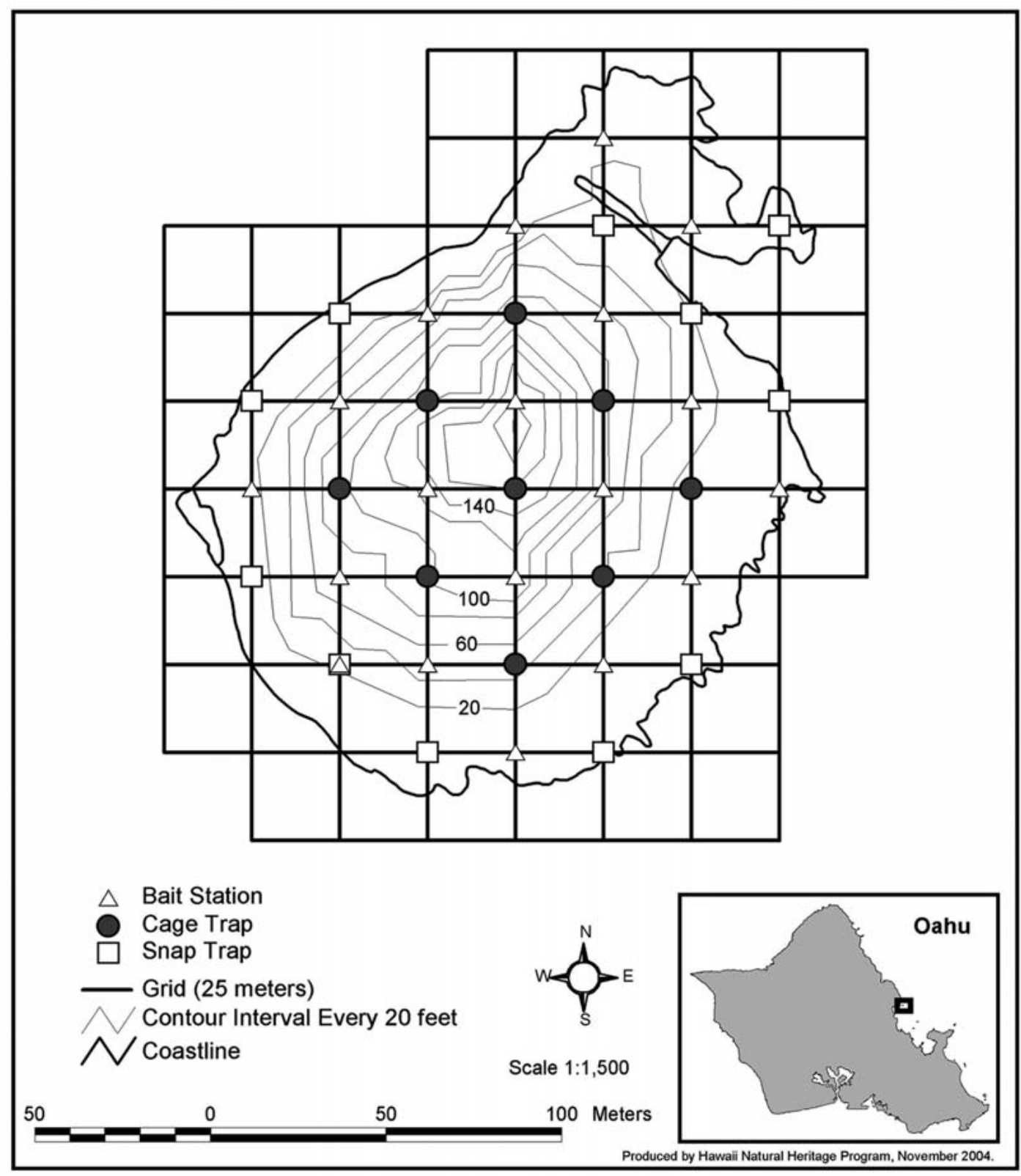

Figure 1. Map showing location of Mokoli'i Islet and grid system used to locate traps and bait stations.

MATERIALS AND METHODS

On 3 March 2002, E.K.S. and 10 volunteers from the local community accessed Mokoli'i Island by sailboat, kayaks, and surfboards from Kualoa Regional Beach Park and set out 19 bait stations, nine cage traps, and 11 snap traps in a $25-\mathrm{m}$ grid across the island (Figure 1). The design was based on a successful rat eradication program previously 


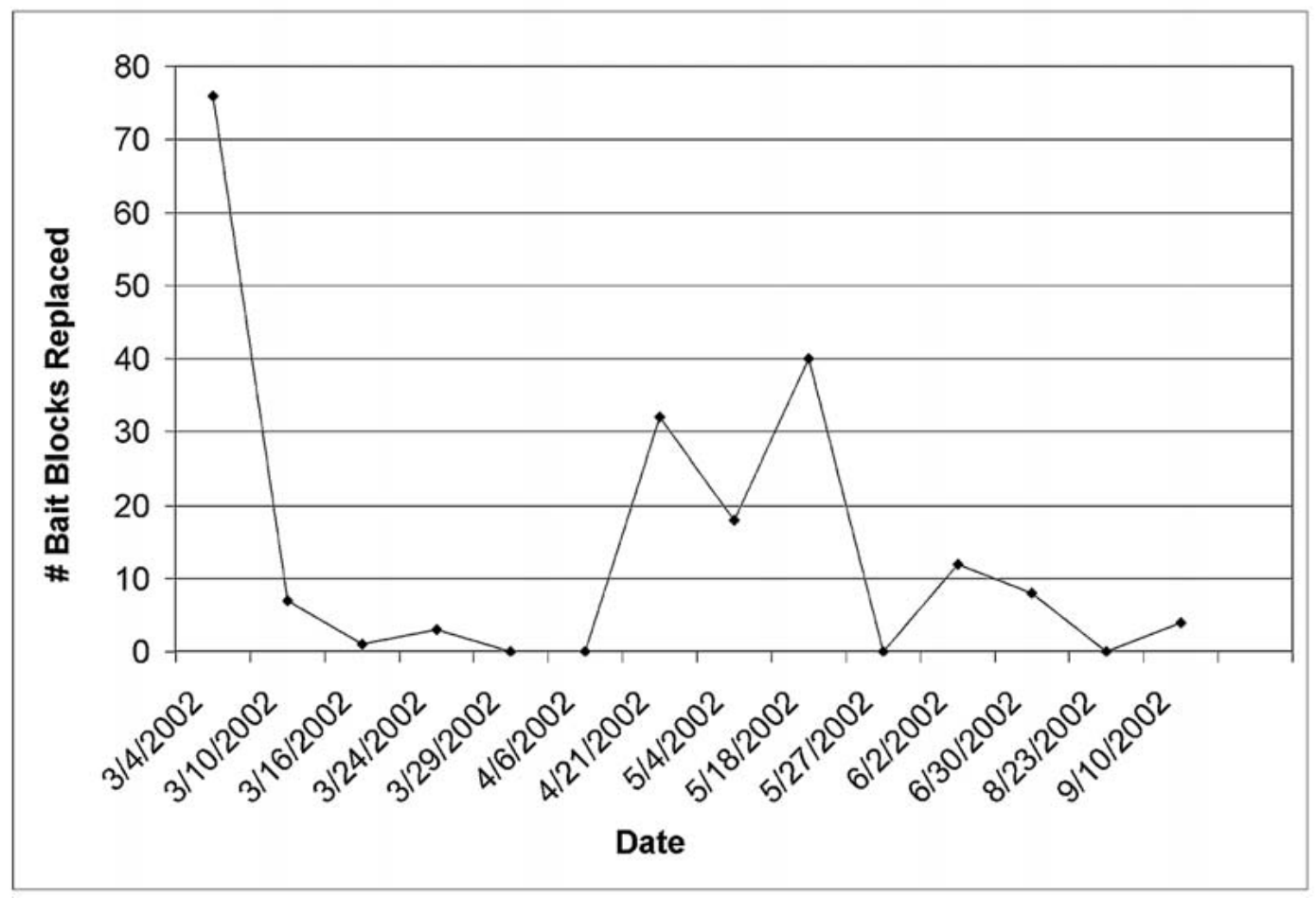

FIgUre 2. Take of diphacinone bait blocks from 19 bait stations on Mokoli'i Islet in 2002.

conducted on Kure Atoll (Division of Forestry and Wildlife 1994). Each bait station was stocked with eight 56.7 -g (2-ounce) blocks of Eaton's brand peanut butter and molasses-flavored bait containing $0.005 \%$ diphacinone, which is blue-green and is the only rodenticide approved for use in Hawai'i. All baiting procedures were conducted in compliance with U.S. Environmental Protection Agency special local need registration HI960008 and with regulations of the Hawai' $i$ State Department of Agriculture. Cage traps (Haguruma, Osaka, Japan) were 46 by 34 $\mathrm{cm}$. Coconut smeared with peanut butter was used to bait the cage traps, and plain peanut butter was used to bait snap traps.

Bait stations and traps were checked the next day, and once a week thereafter, until there was no sign of rat take on the baits and no captures had occurred for several consecutive visits. Checking traps and bait stations after a single day on 4 March addressed the potential for high initial take of bait, provided the opportunity to identify rat specimens to species, and allowed for rats to be dispatched in a timely manner. Sixteen visits were made from March to October to maintain the eradication effort (Figure 2).

Wedge-tailed Shearwaters return to nesting areas in Hawai'i in March or April to select nest sites, lay eggs in early June, and usually fledge in November (Harrison 1990, Whittow 1997). Surveys of the number of shearwater chicks surviving on most islets off $\mathrm{O}^{\mathfrak{s}}$ ahu, including Mokoli' $\mathrm{i}$, are conducted in October each year by the Hawai'i Division of Forestry and Wildlife, providing baseline data for comparison.

\section{RESULTS AND DISCUSSION}

From 3 March through 24 October 2002, 77.5 person-days were spent checking traps and deploying 354 blocks of diphacinone bait. Eighteen black rats were caught in the first 2 weeks; 12 in cage traps and six in snap 


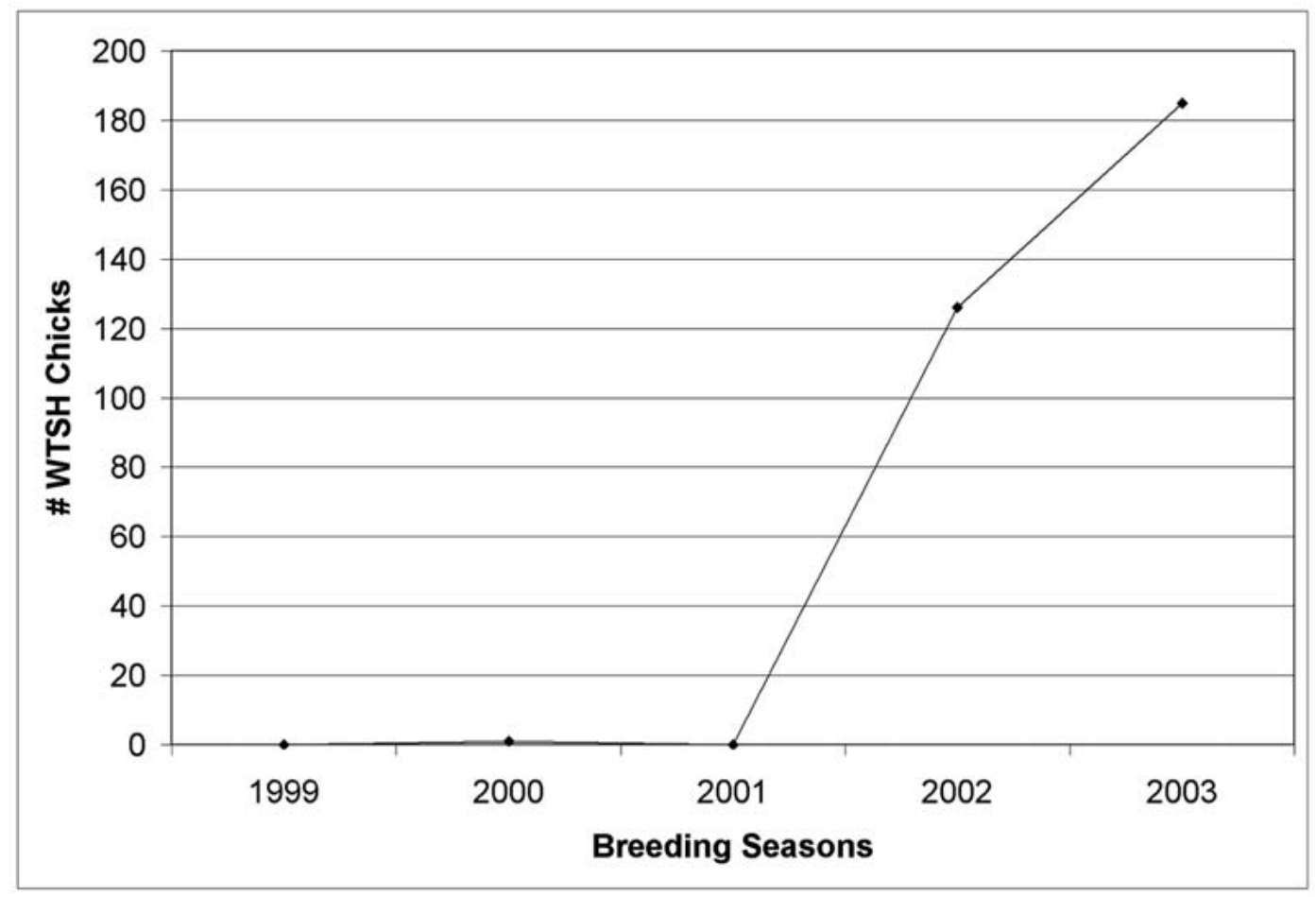

Figure 3. Nesting success of Wedge-tailed Shearwaters on Mokoli'i Island from 1999 to 2003.

traps. No other rodent species were captured. There were no further trap captures after 16 March. Snap traps were removed on 6 April and cage traps were removed on 21 April to save labor. Take of bait was initially high on 4 March, but dropped off rapidly (Figure 2). It is interesting that the take of bait from stations increased again immediately after the traps were removed (Figure 2), indicating there were still rats on the island and that they may have been trap shy, and demonstrating the importance of using more than one method to remove rats. There was a small increase in the bait take from 4 to 18 May (Figure 2), but this was caused by the cumulative foraging by insects over the previous 2 months, rather than by rats. Several rats captured in cage traps were necropsied, revealing that they had ingested the blue-green diphacinone bait. By 27 May there were no indications of rats on the island, and all subsequent bait take was attributable to insects, based on their abundance in the bait stations and by the character of the marks on the bait blocks. Insects tended to eat away the waxy portions of the bait blocks around each individual grain. In contrast, rats tended to gnaw at the bait block, leaving paired tooth marks through the grains.

From 1999 to 2001, before rats were eradicated, only a single Wedge-tailed Shearwater chick survived on Mokoli'i. After rats were eradicated, the number of surviving chicks increased to 126 in 2002 and 185 in 2003 (Figure 3).

In addition to the increased numbers of Wedge-tailed Shearwaters, we noticed increases in other native species, although we did not collect quantitative data on their abundance. Before the eradication attempt there was extensive browsing by rats on naupaka stems and meristems, which killed several of the larger plants, and there were only 10 clumps of Carter's panic grass. Three intertidal invertebrate species that are ubiquitous in Hawai'i, pipipi (Nerita picea), speckled 
periwinkle (Littoraria pintado), and 'a'ama crab (Grapsus tenuicrustatus) (Severns 2000), were all scarce. A survey on 4 March 2003, after rat eradication, found an abundance of common intertidal species, including pipipi, periwinkle, and 'a'ama crab, in the same areas where they were previously scarce, and naupaka that had been damaged by rat grazing had resprouted with the annual winter rainfall.

This project was successful in eradicating rats on Mokoli'i Island, but it is possible that rats may recolonize the island by stowaways on private boats that visit the island or by the intentional actions of people. Continued vigilance of nesting seabirds and rats will be necessary to ensure that the island continues to provide predator-free nesting habitat. This project would not have been possible without the support, participation, and enthusiasm of the local community. Their work greatly facilitated the effort, reduced the cost, and demonstrated how much can be achieved with dedicated volunteers. Continued participation by the local community in monitoring for rats and seabirds will be essential to the continued success of this program.

\section{ACKNOWLEDGMENTS}

The State of Hawai'i, Division of Forestry and Wildlife, extends its sincere thanks to Charlie Reppun, Paul Reppun, Nick Reppun, Fred Reppun, David Reppun, Vivien Lee, Ho'ala Fraiola, Ka'ua Fraiola, Jane Beachy, Martha Beachy, Kailenui Dickson, and Natcha Enesa for their interest in and carrying out the majority of the labor required to complete the rat eradication effort on Mokoli'i. We also thank Linda Fujihara, Park Director, Kualoa Regional Park, for supporting community interest in restoring and preserving the offshore island resources; Dwight Matsuwaki, Geographic Information System Specialist of the Hawaici Natural Heritage Program for developing the map of Mokoli'i Island; and the City and County of Honolulu for providing the elevation contour data for the map. Valuable comments on the manuscript were made by David Towns and an anonymous reviewer.

\section{Literature Cited}

Atkinson, I. A. E. 1977. A reassessment of factors, particularly Rattus rattus L., that influenced the decline of endemic forest birds in the Hawaiian Islands. Pac. Sci. 31:109-133.

- 1985. The spread of commensal species of Rattus to oceanic islands and their effects on island avifaunas. Int Counc. Bird Preserv. Tech. Publ. 3:35-81.

Division of Forestry and Wildlife, O'ahu District Wildlife Branch, Hawai'i. 1994. Pittman-Robertson Fund, grant expenditure report, fiscal year 1993/1994. Offshore islands, Kure Atoll, rat eradication. Available from the Division of Forestry and Wildlife, Honolulu, Hawaici.

Harrison, C. S. 1990. Seabirds of Hawaii: Natural history and conservation. Cornell University Press, Ithaca, New York.

McLennan, J. A., M. A. Potter, H. A. Robertson, G. C. Wake, R. Colbourne, L. Dew, L. Joyce, A. J. McCann, J. Miles, P. J. Miller, and J. Reid. 1996. Role of predation in the decline of Kiwi, Apteryx spp., in New Zealand. N. Z. J. Ecol. 20:27-35.

Moors, P. J., I. A. E. Atkinson, and G. H. Sherley. 1992. Reducing the rat threat to island birds. Bird Conserv. Int. 2:93114.

Severns, M. 2000. Hawaiian seashells. Island Heritage Publishing, 'Aiea, Hawai'i.

Tomich, P. Q. 1986. Mammals in Hawaii: A synopsis and notational bibliography. Bishop Museum Press, Honolulu, Hawai $i$ i.

Wagner, W. L., D. R. Herbst, and S. H. Sohmer. 1999. Manual of the flowering plants of Hawai'i, rev. ed. University of Hawai'i Press and Bishop Museum Press, Honolulu.

Whittow, G. C. 1997. Wedge-tailed Shearwater (Puffinus pacificus). In A. Poole and F. Gill, eds. The Birds of North America, No. 305. The Birds of North America, Inc., Philadelphia, Pennsylvania.

Zino, F., P. Oliveira, S. King, A. Buckle, M. Biscoito, H. Costa Neves, and A. Vasconcelos. 2001. Conservation of Zino's Petrel Pterodroma madeira in the archipelago of Madeira. Oryx 35:128-136. 
